\title{
PREDICTION OF THERMAL COMFORT AND ENERGY BEHAVIOUR THROUGH NATURAL-BASED SOLUTIONS IMPLEMENTATION: A CASE STUDY IN BADAJOZ, SPAIN
}

\author{
GUADALUPE GÓMEZ ${ }^{1}$, BORJA FRUTOS ${ }^{1}$, CARMEN ALONSO ${ }^{1}$, FERNANDO MARTÍN-CONSUEGRA ${ }^{1}$, \\ IGNACIO OTEIZA ${ }^{1}$, MARTA M. CASTELLOTE ${ }^{1}$, JESÚS MUÑOZ ${ }^{2}$, SALUSTIANO TORRE ${ }^{2}$, \\ JOSE FERMOSO ${ }^{3}$, TEBA TORRES ${ }^{3}$, MIGUEL A. ANTÓN $^{4}$, TERESA BATISTA ${ }^{5} \&$ NUNO MORAIS $^{6}$ \\ ${ }^{1}$ IETcc-CSIC (Instituto Eduardo Torroja de Ciencias de la Construcción-CSIC), Spain \\ ${ }^{2}$ RJB-CSIC (Real Jardín Botánico-CSIC), Spain \\ ${ }^{3}$ Centro Tecnológico CARTIF, Spain \\ ${ }^{4}$ Área de Desarrollo Rural y Sostenibilidad, Diputación de Badajoz (DIPBA), Spain \\ ${ }^{5}$ CIMAC (Comunidade Intermunicipal de Alentejo Central), Portugal \\ ${ }^{6}$ Câmara Municipal do Porto, Portugal
}

\begin{abstract}
Climate change impacts particularly affect vulnerable populations such as children. Therefore, it is necessary to address the adaptation of educational buildings to prevent their negative impact on school performance and to increase their resilience. This study is part of an ongoing project, LIFE myBUILDINGisGREEN (LIFE17 CCA/ES/000088), which aims to optimise learning conditions in schools in southern Europe affected by heat waves during warmer months. This first part of the project focuses on predicting the impact of nature-based solutions (NBS) implementation. The main concern of this stage is to analyse the benefits on both interior comfort and energy efficiency. This paper presents the results of the influence on space cooling demand via dynamic building simulations after successively applying the different NBS. Further improvements in indoor environmental conditions such as $\mathrm{CO}_{2}$ concentration reductions will be evaluated later. For this purpose, a demonstration building, located in southern Spain, characterized in terms of thermophysical parameters of the envelope and air infiltrations was selected. The energy model was calibrated with actual monitoring data. Different scenarios have been analysed through an energy prediction software, leading to a wide range of outcomes in terms of improvements in both energy demand - assuming a cooling system - and temperature reduction.
\end{abstract}

Keywords: climate change, heatwaves, health, educational buildings, nature-based solutions, energy efficiency, indoor environmental quality, monitoring, dynamic simulations.

\section{INTRODUCTION}

Climate change is now recognized as one of the most serious environmental, social and economic challenges facing the world. Many of the global risks of climate change are concentrated in urban areas. The impacts of climate change, such as heat waves, changes in annual and seasonal rainfall patterns, are particularly affecting the well-being and the health of the most vulnerable members of the population, such as children, who spend a third of their lives inside their schools [1]. Insufficient regulation to address these new risks at schools, combined with low budget allocation, make it necessary to focus on the adaptation of these buildings to prevent the negative impacts of climate change in school performance [2].

In research carried out by monitoring three schools in Madrid during a complete year, it was determined that only $30 \%$ of the teaching hours reached adequate indoor hygrothermal conditions, while adequate air quality was achieved during $64 \%$ of those hours [3]. This is why LIFE myBUILDINGisGREEN project (LIFE17 CCA/ES/000088 - LIFE mBiG) focuses on this building sector: educational centres located in southern Europe. It aims to implement passive measures to improve the resilience of these buildings and to accelerate 
their adaptation to new climate conditions. This is proposed to be achieved through implementing nature-based solutions (NBS) as prototypes, inspired and supported by nature, for climate adaptation and improving the well-being of these buildings' users.

The advantages of NBS implementation are multiple. It is well known that the application of NBS in urban environment [4] demonstrates a significant increase in human resilience and well-being in cities during increasingly hot summers [5]. A wide characterization of different implementation options is available both for urban and built environments [6].

Incorporating passive measures contributes, in most cases, to the reduction of energy consumption in existing buildings. Some of these innovative actions are green roofs, green shadow structures for walls or natural ventilation measures. With regard to the latter action, as a complementary to the use of various NBS, it will promote a significant decrease in the indoor temperature and energy consumption [7], and improve the air quality [2], [8]. National and international regulations offer many options and guidelines for the design of different ventilation protocols [9], [10].

\section{MATERIALS AND METHODS}

This paper presents the baseline scenario for the selection and design of the NBS to optimize hygrothermal comfort in the demonstration buildings. The aim is to evaluate indoor comfort during the summer in the educational establishments and to predict the improvement potential provided by NBS-based actions. These actions include green roofs and the shading of the façades using the green prototypes developed in $\mathrm{mBiG}$ Project. The study developed for the pilot school located in Badajoz (demonstration building \#1) is presented here.

\subsection{Demonstration building}

Pilot schools were chosen at a previous stage on the basis of a selection matrix, composed of a series of characteristics that the buildings have to fulfil. These characteristics were gathered into three main blocks: construction features, population size and other requirements

The study case presented in this paper is the school "CEIP Gabriela Mistral" located in Solana de los Barros, Badajoz (Spain), coordinates $38^{\circ} 43^{\prime} \mathrm{N} 6^{\circ} 32^{\prime} \mathrm{W}$. It is the first of three selected demonstration buildings where NBS will be applied in the context of the LIFE $\mathrm{mBiG}$ Project. The NBS solutions will be implemented in the building highlighted in green (Fig. 1).

The characteristics of the envelope are the following: four flat roofs that are not currently walkable, except for maintenance purposes. The main façades are facing east and west. They

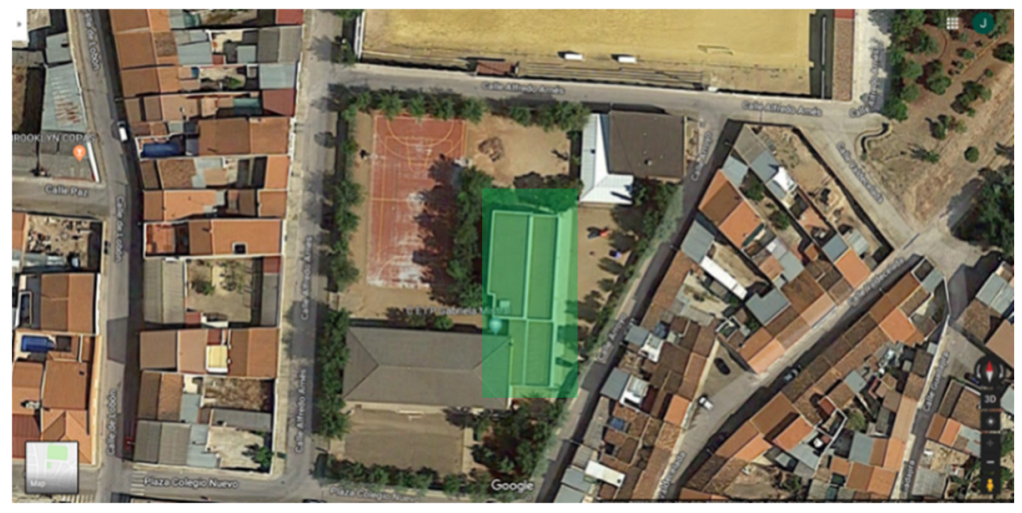

Figure 1: View of CEIP Gabriela Mistral School. (Source: Google Maps.) 
are constructed including a non-ventilated air gap. Walls include large windows in both orientations, including an important glassed surface on a roofed passageway facing east.

\subsection{The climate of Badajoz}

The climate of Badajoz is typified as continental Mediterranean with hot and dry summers, while winters are cool and partly cloudy. The warm season lasts 3.0 months, from 14 June to 13 September, and the average daily maximum temperature is over $30^{\circ} \mathrm{C}$. The hottest day of the year is $29 \mathrm{July}$, with an average maximum temperature of $35^{\circ} \mathrm{C}$ and an average minimum temperature of $18^{\circ} \mathrm{C}$. The cold season lasts four months, from 16 November to $4 \mathrm{March}$, with average daily maximum temperature under $18^{\circ} \mathrm{C}$. The coldest day of the year is 18 January, with an average minimum temperature of $3^{\circ} \mathrm{C}$ and an average maximum of $14^{\circ} \mathrm{C}$ (data from https://es.weatherspark.com).

The psychometric abacus has been used to support the analysis of comfort parameters and the proposal of passive improvement solutions. The temperature and relative humidity conditions are represented for each hour of the summer, and the most appropriate passive strategies to achieve comfortable conditions are indicated (Fig. 2).

From May to October inclusive, maximum daily temperatures rise above $27^{\circ} \mathrm{C}$. As pointed out in the abacus, during the summer it should be possible to achieve almost $100 \%$ comfort hours without using active air conditioning systems. This would be possible by incorporating

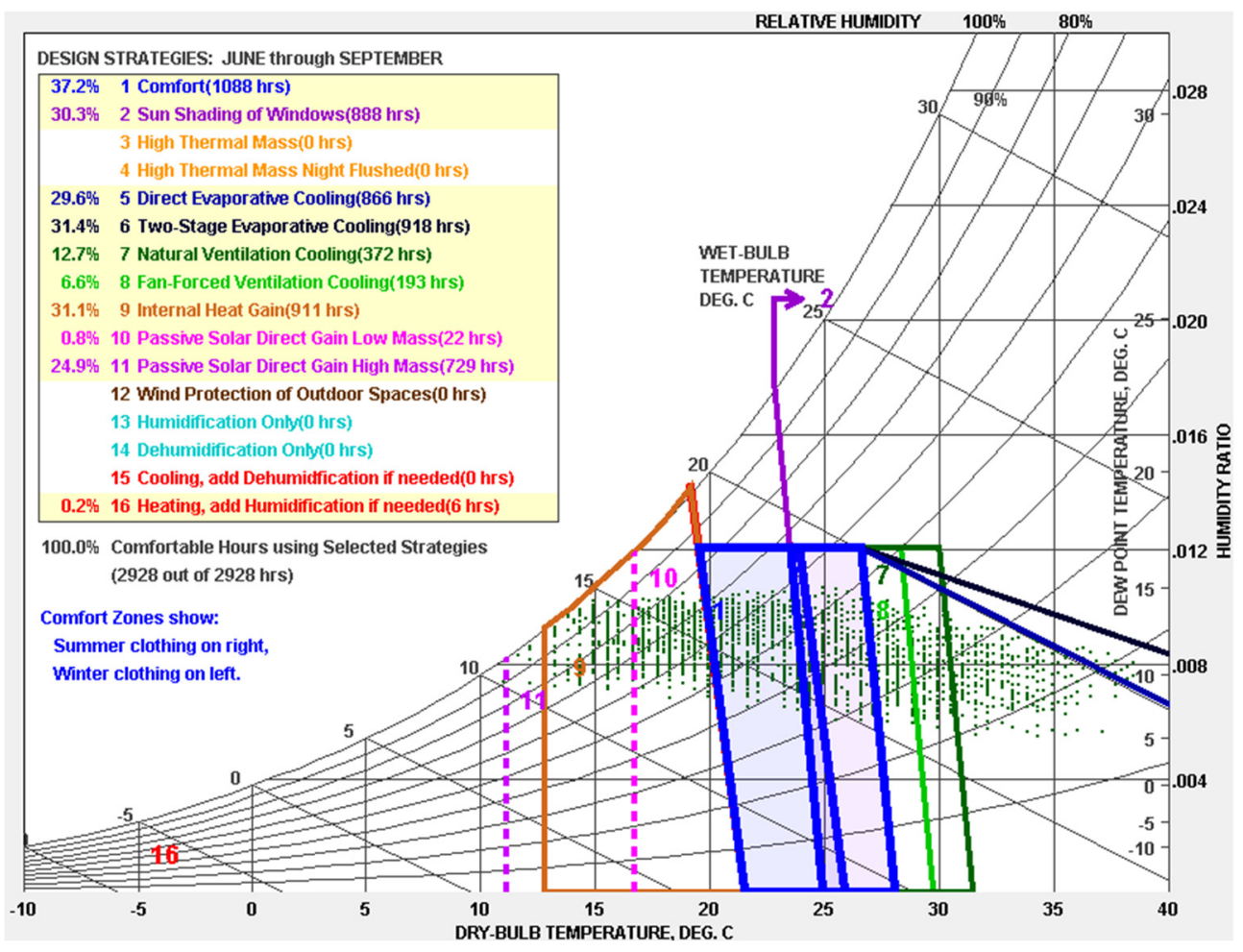

Figure 2: Psychrometric abacus including passive improvement measures for summer. (Source: Climate Consultant, Department of Architecture and Urban Design, UCLA 2018.) 
appropriate passive measures such as: flat reflective roof, windows shading (maximum shade in summer and minimum in winter), evaporative cooling systems, thermal inertia inclusion, night ventilation, internal load management and use of ceiling fans. None of the proposed strategies should negatively influence the bioclimatic behaviour of the building in winter.

The research has been carried out by monitoring outdoor temperatures with the support of AEMET data during the months in which no records were collected. For this stage, the outdoor climate data from the meteorological observatory located at the Badajoz Airport $\left(38^{\circ} 53^{\prime} 00.0\right.$ "N $\left.6^{\circ} 48^{\prime} 50.0 \mathrm{~W}\right)$ were taken. The daily interval data are open access through the web site www.aemet.es/. Fig. 3 shows the results of the outdoor temperatures: the standard year (US Department of Energy's EPW (Energy Plus Weather) database), 2019 records (AEMET) and the outdoor sensor records from October to December monitored in this project.

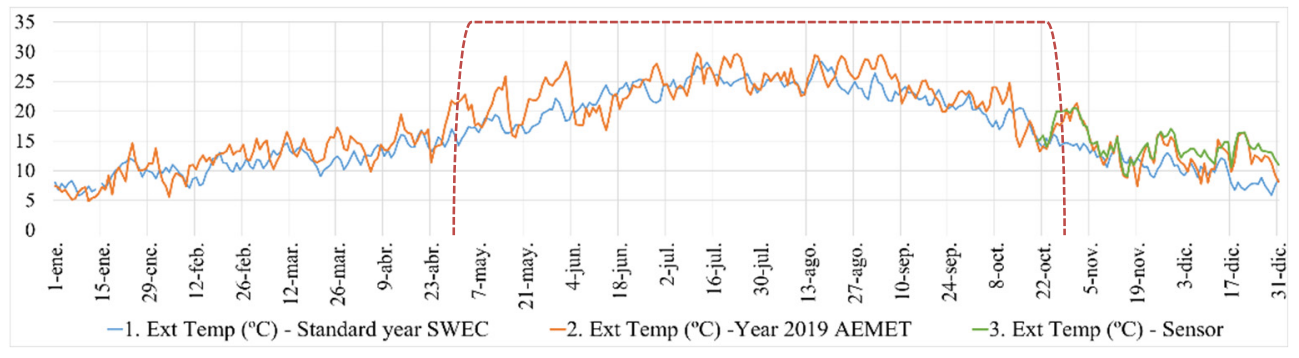

Figure 3: Outdoor daily temperatures for a full year. (1) Data from a standard year (Source: US DOE); (2) Data from 2019 (Source: AEMET); and (3) Monitored data (Source: Authors' formulation).

Data recorded in 2019 show higher temperatures throughout the year than data for a standard year. In particular, a higher incidence of heat waves is observed. Outdoor temperature peaks can be identified, as heat waves that took place during the months of May, July and August 2019.

\subsection{Indoor environmental quality (IEQ) characterisation}

A Testo 160 IAQ data logger was placed to record classroom temperature, relative humidity, $\mathrm{CO}_{2}$ concentration and barometric pressure. Temperature accuracy is $\pm 0.5^{\circ} \mathrm{C}$ and resolution is $0.1{ }^{\circ} \mathrm{C}$. Relative humidity accuracy is $\pm 3 \%$ and resolution is $0.1 \% \mathrm{RH} . \mathrm{CO}_{2}$ concentration accuracy is $\pm 3 \%$ and resolution is $1 \mathrm{ppm}$. Data was collected every 15 minutes.

To determine discomfort hours, the indoor temperatures were analysed. The sensor was located in a standard classroom, with an area of $54.44 \mathrm{~m}^{2}$ and a clear height of $2.84 \mathrm{~m}$. No student occupation was reported during monitoring. Furthermore, it was non-ventilated from May to September. Teaching hours are from 9:00 a.m. to 3:00 p.m., from Monday to Friday. The months of July and August are not considered as a teaching period.

Official guidelines established by the Instituto Nacional de Seguridad y Salud en el Trabajo [11] have been used to evaluate comfort levels. A maximum temperature of $27^{\circ} \mathrm{C}$ is set for sedentary work performed in an office. This value is taken as a reference for this research during months of May, June and September (Fig. 4). Table 1 shows number of hours of discomfort during this period. 


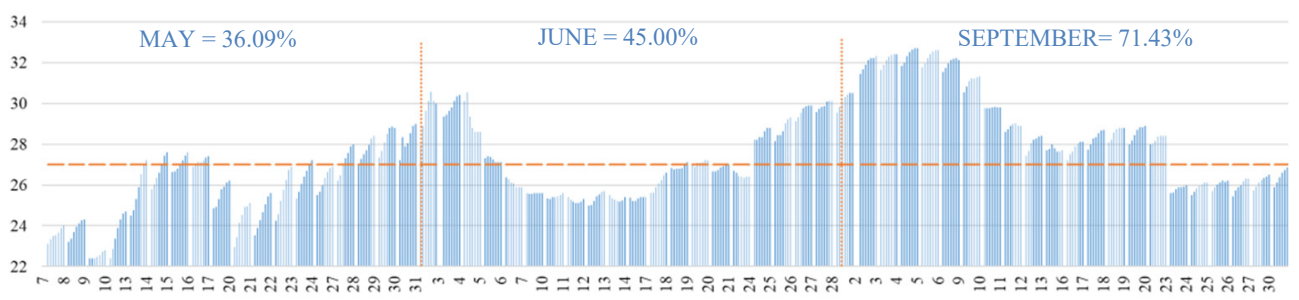

Figure 4: Hours outside comfort within the teaching period. From 9:00 a.m. to 3:00 p.m., from Monday to Friday, during May, June and September. Monitored data of the reference classroom. (Source: Authors' formulation.)

Table 1: Comparison of teaching hours in discomfort. (Source: Authors' formulation.)

\begin{tabular}{|l|c|c|c|}
\hline Lective month & Lective hours & Discomfort hours & \% discomfort \\
\hline May & 133 & 48 & $36.09 \%$ \\
\hline June & 140 & 63 & $45.00 \%$ \\
\hline September & 147 & 105 & $71,43 \%$ \\
\hline
\end{tabular}

\subsection{Simulation model}

Design Builder, version 4.7 was used as energy simulation tool. This program provides the possibility of optimizing an efficient design of buildings, through dynamic simulations of their thermal behaviour. The EnergyPlus calculation engine supports it. Climate data of the standard year for Badajoz has been selected (Fig. 5).

A template was used for the simulation model, "Teaching areas which include classrooms and corridors providing access to and between classrooms". Occupation is not considered for the calibration of the model. Since the monitored classroom was unoccupied during the tested

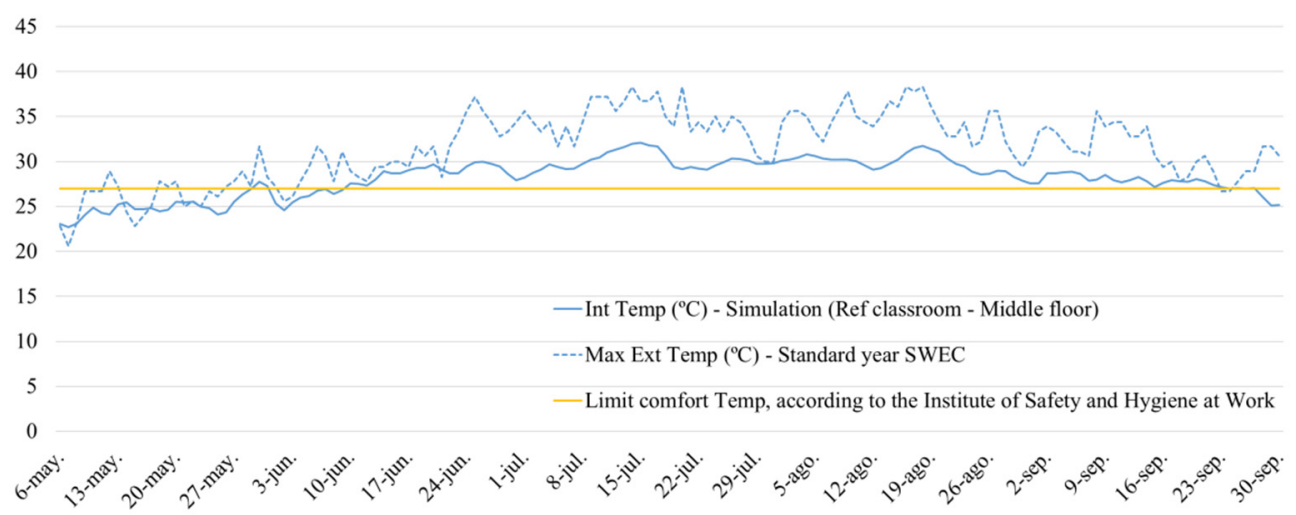

Figure 5: Simulated daily data for the reference classroom (located on the middle floor) without occupation and with no ventilation protocols. Maximum outdoor temperature data for the standard year. (Source: US DOE EPW and authors' formulation.) 
period. For the NBS implementation scenarios, an occupation profile is applied to the model. This profile is defined as an educational activity. Teaching hours are considered from 9:00 a.m. to 3:30 p.m. from Monday to Friday, being "Off" on Saturdays and Sundays. Climate data, defined in the SWEC database compiled by the University of UCLA (University of California, Los Angeles) for EnergyPlus calculation engine, are taken into account to define the standard year.

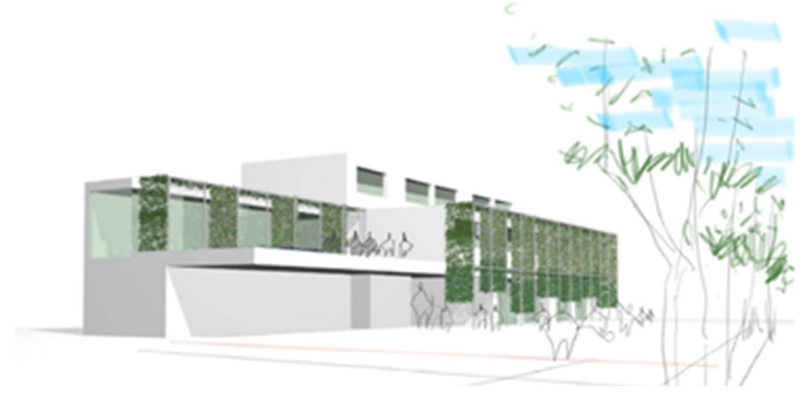

Figure 6: Render of the green wall on the east façade: FAVE system. (Source: Authors' formulation.)

Different NBS implementation scenarios are introduced consecutively by addition:

Scenario 0: Current state (EI). The building is modelled considering each floor as a separate zone. Occupancy of $0.3 \mathrm{p} / \mathrm{m}^{2}$ is considered.

- Scenario 1: Green façade system (FAVE) on the east façade.

- Scenario 2: Scenario 1 plus Tree System (SA) on the west façade.

- Scenario 3: Scenario 2 plus green roof (CUVE).

- Scenario 4: Scenario 3 plus natural ventilation (VN). An air change rate (ACH) of $5 \mathrm{~h}^{-1}$ during the night is modelled. The calculated value according to the Spanish regulation RITE to guarantee a good indoor air quality was used for this purpose (Table 2).

Table 2: Air change rate according to RITE. Good indoor air quality level (IDA 2).

\begin{tabular}{|c|c|c|c|c|c|}
\hline $\begin{array}{c}\text { Classroom } \\
\text { area }\left(\mathrm{m}^{2}\right)\end{array}$ & Height $(\mathrm{m})$ & $\begin{array}{c}\text { No. of } \\
\text { students }\end{array}$ & $\begin{array}{c}\text { Flow }(\mathrm{l} / \mathrm{s}) \mathrm{x} \\
\text { person }\end{array}$ & $\begin{array}{c}\text { Spanish } \\
\text { standard }\end{array}$ & $\begin{array}{c}\text { Air change } \\
\text { rate }\left(\mathrm{h}^{-1}\right)\end{array}$ \\
\hline 54.44 & 2.84 & 16 & 12.5 & RITE-IDA2 & 4.7 \\
\hline
\end{tabular}

Component blocks were used to simulate shading for the different scenarios. They are "solid" blocks that do not generate thermal zones (they do not conduct heat). The blocks allow the wind passing through.

The consideration of the surroundings is included in the model: the heights of the plants and the definition of nearby buildings respond to the plans provided by the Diputación de Badajoz. The thermal characterization of the envelope is simulated as outlined in Table 3. 


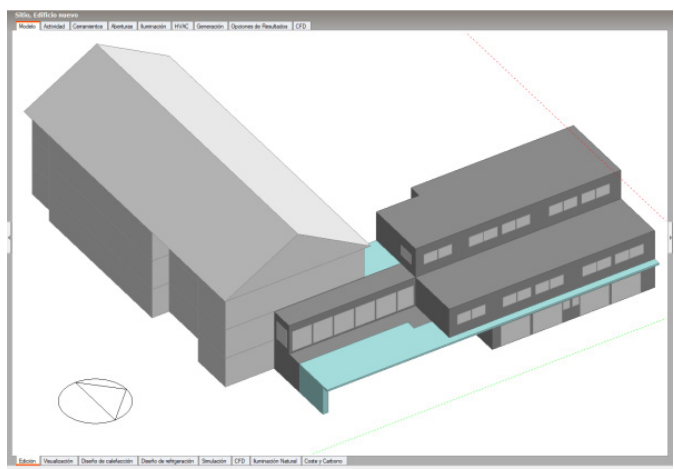

(a)

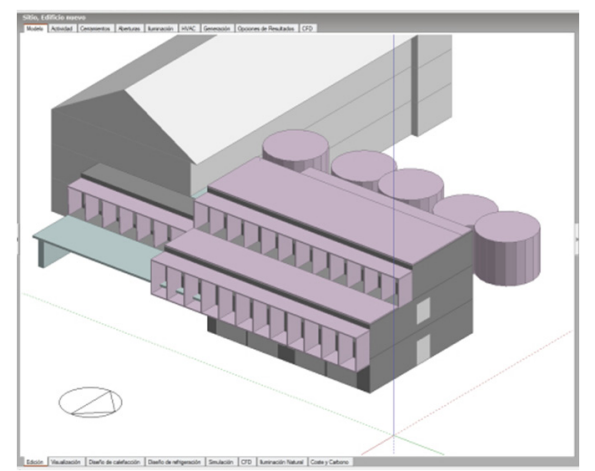

(b)

Figure 7: Image of the energy model for the case study. (a) Current state (Scenario 0); and (b) Incorporation of the NBS (Scenarios 3-4). (Source: Authors' formulation using Design Builder 4.7.)

Table 3: Constructive description.

\begin{tabular}{|c|c|c|}
\hline \multirow{2}{*}{ Element } & \multicolumn{2}{|c|}{ Composition } \\
\hline & Before NBS implementation & After NBS implementation \\
\hline $\begin{array}{l}\text { Exterior } \\
\text { wall }\end{array}$ & $\begin{array}{l}\text { Gypsum plaster } 1.5 \mathrm{~cm} \\
\text { Ceramic brick } 7 \mathrm{~cm} \\
\text { Air gap not ventilated } \\
\text { PUR Polyurethane } 4 \mathrm{~cm} \\
\text { Cement mortar } 1 \mathrm{~cm} \\
\text { Brick wall } 15 \mathrm{~cm} \\
\text { Cement plaster } 1.5 \mathrm{~cm}\end{array}$ & $\begin{array}{l}\text { Gypsum plaster } 1.5 \mathrm{~cm} \\
\text { Ceramic brick } 7 \mathrm{~cm} \\
\text { Air gap not ventilated } \\
\text { PUR Polyurethane } 4 \mathrm{~cm} \\
\text { Cement mortar } 1 \mathrm{~cm} \\
\text { Brick wall } 15 \mathrm{~cm} \\
\text { Cement plaster } 1.5 \mathrm{~cm} \\
\text { Plus FAVE system (scaffolding structure } \\
\text { with plants anchored to vertical wall on } \\
\text { east façade) - component block } \\
\text { Plus SA (group of trees on west façade) - } \\
\text { component block }\end{array}$ \\
\hline Roof & $\begin{array}{l}\text { Gypsum plaster } 1 \mathrm{~cm} \\
\text { Concrete slab } 25+5 \mathrm{~cm} \\
\text { Cast concrete (lightweight) } 10 \mathrm{~cm} \\
\text { Cement mortar } 2 \mathrm{~cm} \\
\text { Waterproofing layer } 4 \mathrm{~kg} / \mathrm{m}^{2} \\
\text { Polyester resin } 150 \mathrm{~g} / \mathrm{m}^{2} \\
\text { Extruded polystyrene } 40 \mathrm{~mm} \\
\text { Polyester resin } 150 \mathrm{~g} / \mathrm{m}^{2} \\
\text { Aggregate gravel } 5 \mathrm{~cm}\end{array}$ & $\begin{array}{l}\text { Gypsum plaster } 1 \mathrm{~cm} \\
\text { Concrete slab } 25+5 \mathrm{~cm} \\
\text { Cast concrete (lightweight) } 10 \mathrm{~cm} \\
\text { Cement mortar } 2 \mathrm{~cm} \\
\text { Waterproofing layer } 4 \mathrm{~kg} / \mathrm{m}^{2} \\
\text { Polyester resin } 150 \mathrm{~g} / \mathrm{m}^{2} \\
\text { Extruded polystyrene } 40 \mathrm{~mm} \\
\text { Polyester resin } 150 \mathrm{~g} / \mathrm{m}^{2} \\
\text { (Without aggregate gravel) } \\
\text { Plus air ventilated gap } 10 \mathrm{~cm} \\
\text { Plus system with a topsoil layer } 10-20 \mathrm{~cm} \\
\text { - component block }\end{array}$ \\
\hline
\end{tabular}


Regarding the airtightness, no mechanical ventilation nor daily natural ventilation are defined. Infiltrations are considered by an air change rate of $0.7 \mathrm{~h}^{-1}$.

Indoor temperature and cooling demand analysis are run from May to the end of September. Indoor temperature results for the different scenarios are taken from the middle floor to compare with data from the monitored classroom. The whole building's cooling demand is also assessed. The cooling system was simulated as an electric standard cooling system with operating coefficient of $100 \%$.

\section{RESULTS AND DISCUSSION}

Indoor temperature reduction results, due to NBS shading techniques, are given. On the other hand, actual cooling demand is analysed and compared with NBS reduction potential.

\subsection{Indoor temperature}

Daily average temperature in the month of June is presented in Fig. 8. A single month performance is displayed to allow a clearer visualization. It shows indoor temperature reduction in successive NBS incorporation. It can be observed that it is possible to low them below $27^{\circ} \mathrm{C}$, as a temperature regulatory limit at workplaces.

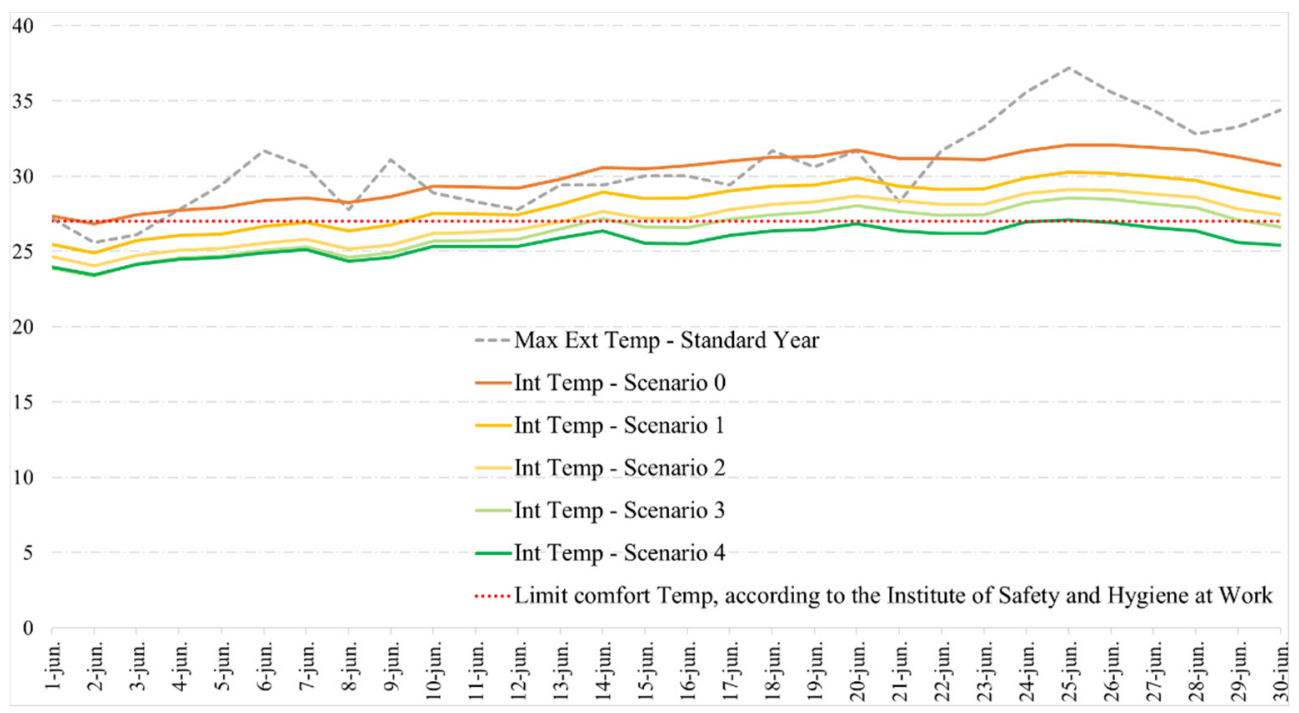

Figure 8: Mean daily temperatures, after applying NBS, for the month of June.

Notice that natural ventilation is not applied in Scenario 0 and results are similar to those obtained in on-site monitoring. In successive stages, a model adjustment to real ventilation patterns will be undertaken.

As shown in Fig. 9, improvement on indoor temperature reduction is remarkable when natural ventilation at night is considered in the model (Scenario 4). Every colour represents temperature percentage reduction from May to September. Mean temperatures are also represented. 


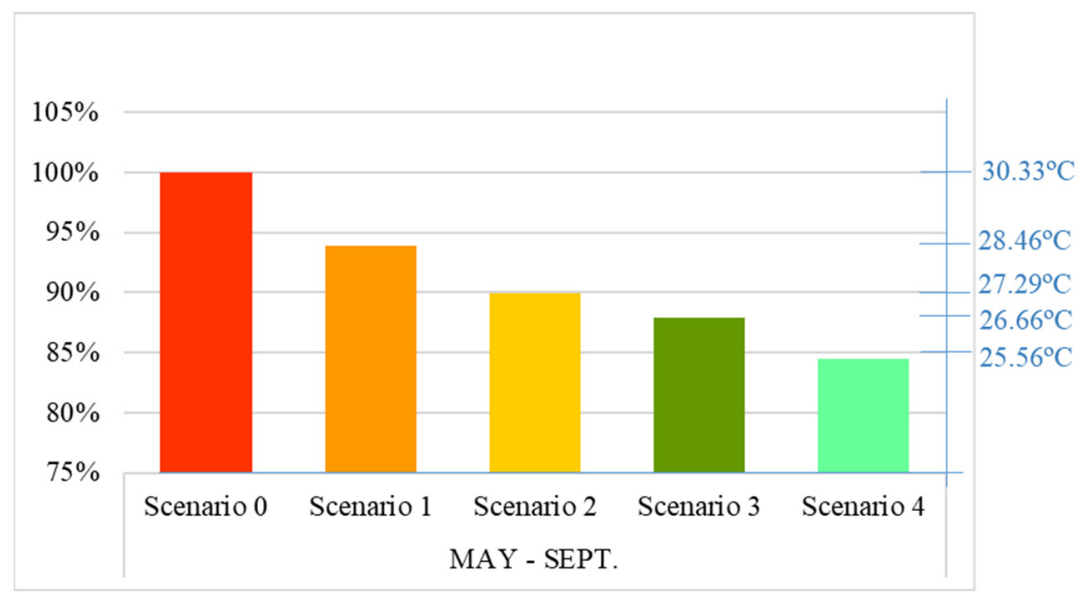

Figure 9: Mean temperature reduction, after applying scenarios in the model. Simulation form from May to September.

Table 4 illustrates indoor temperature reduction from Scenarios 0 to 4 . It can be seen that largest reduction occurs between Scenario 0 and 1. Incorporating the NBS on the roof, from Scenario 2 to 3, produce smalls changes in temperature. It can be explained due to model limitation in simulation green roof behaviour. Plant features such as evapotranspiration, reflectance, density and leaf area index, remain undefined. This will be taken into account in future steps of the research.

Table 4: Rate of temperature reduction $\left({ }^{\circ} \mathrm{C}\right)$ for each scenario referred to Scenario 0 .

\begin{tabular}{|l|c|c|c|c|c|c|c|c|c|}
\hline Month & $\begin{array}{c}\text { Scenario } \\
\mathbf{0}\end{array}$ & \multicolumn{2}{|c|}{ Scenario 1 } & \multicolumn{2}{|c|}{ Scenario 2 } & \multicolumn{2}{|c|}{ Scenario 3 } & \multicolumn{2}{|c|}{ Scenario 4 } \\
\hline & $\mathbf{\%}$ & $\mathbf{\%}$ & $\begin{array}{c}{ }^{\circ} \mathbf{C} \\
\text { less }\end{array}$ & $\mathbf{\%}$ & $\begin{array}{c}{ }^{\circ} \mathbf{C} \\
\text { less }\end{array}$ & $\mathbf{\%}$ & $\begin{array}{c}{ }^{\circ} \mathbf{C} \\
\text { less }\end{array}$ & $\%$ & $\begin{array}{c}{ }^{\circ} \mathbf{C} \\
\text { less }\end{array}$ \\
\hline May & 100.00 & $\mathbf{9 4 . 1 7}$ & 1.51 & $\mathbf{8 9 . 3 8}$ & 2.76 & $\mathbf{8 7 . 7 2}$ & 3.19 & $\mathbf{8 7 . 6 0}$ & 3.22 \\
\hline June & 100.00 & $\mathbf{9 3 . 7 7}$ & 1.87 & $\mathbf{9 0 . 0 3}$ & 2.99 & $\mathbf{8 7 . 9 9}$ & 3.60 & $\mathbf{8 5 . 3 2}$ & 4.41 \\
\hline July & 100.00 & $\mathbf{9 3 . 1 0}$ & 2.27 & $\mathbf{8 9 . 1 0}$ & 3.59 & $\mathbf{8 6 . 7 6}$ & 4.36 & $\mathbf{8 1 . 4 8}$ & 6.10 \\
\hline August & 100.00 & $\mathbf{9 3 . 4 1}$ & 2.17 & $\mathbf{8 9 . 5 1}$ & 3.45 & $\mathbf{8 7 . 1 2}$ & 4.23 & $\mathbf{8 1 . 6 5}$ & 6.03 \\
\hline September & 100.00 & $\mathbf{9 4 . 7 8}$ & 1.56 & $\mathbf{9 1 . 8 4}$ & 2.44 & $\mathbf{9 0 . 0 4}$ & 2.98 & $\mathbf{8 6 . 2 4}$ & 4.11 \\
\hline
\end{tabular}

\subsection{Analysis of cooling demand reduction}

Fig. 10(a) provides results of simulation in cooling demand. Scenario 0 includes a fictitious standard cooling system to compute the baseline demand (represented as $100 \%$ ). As can be seen, scenario 4 reaches up to $40 \%$ of reduction.

Fig. 10(b) illustrates the estimated cooling demand according to the energy efficiency scale. It shows two steps improvement between Scenarios 0 and 4.

Future efforts will focus on understanding behaviour in plants evaporative process and substrate moisture content. The purpose will be to achieve greater consistency between the 


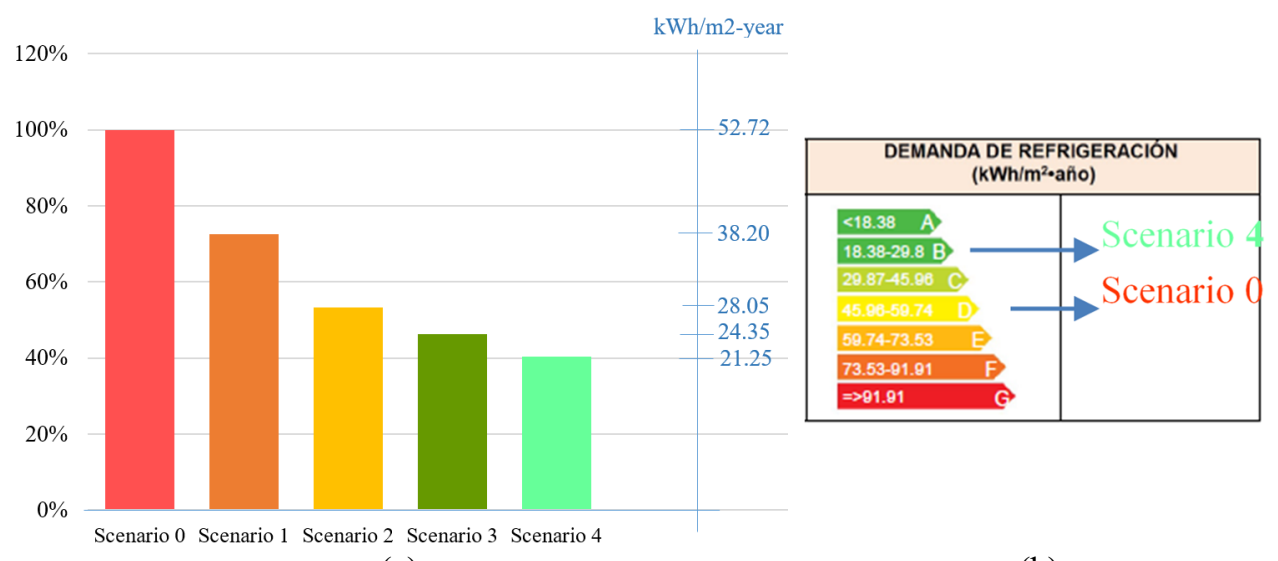

(a)

(b)

Figure 10: (a) Annual rate reduction in cooling demand after implementation of NBS; and (b) Upgrade in the energy efficiency scale, scenario 0 to 4 , www.idae.es.

model and the real performance expected from this kind of solutions. In this way, the integration of NBS into energy efficiency certificates as eligible improvement options would become possible. Additionally, NBS impacts on winter months should be analysed in order to assess the heating demand.

\section{CONCLUSIONS}

In the present paper, the effects of different nature-based solutions implementation on energy demand and temperature reduction were assessed through an energy simulation software. Initially, climate data of the standard year were compared with those registered in 2019. This analysis allowed us to visualize the increasing frequency of heat waves. Subsequently, discomfort hours within teaching period were characterized to identify the initial baseline. The resulting percentage of discomfort hours varied from $40 \%$ to more than $70 \%$, in concordance with previous research in extensive school monitoring. Against this background, energy demand and temperature reduction were estimated. Firstly, the addition of different NBS implied a reduction of nearly $60 \%$ in cooling demand when all scenarios were implemented. Secondly, mean values of temperature reduction were analysed monthly. And the range of indoor temperature reduction varied from $1.5^{\circ} \mathrm{C}$ to $6.1^{\circ} \mathrm{C}$. These figures confirm that the use of NBS will make it possible to fulfil the objectives of the LIFE mBiGProject, which were a cooling demand reduction of $50 \%$ and diminishing indoor temperature $5^{\circ} \mathrm{C}$. This study provides an initial approach to the promising improvements of NBS incorporation on educational buildings. Future developments should also consider improvements in indoor environmental conditions such as $\mathrm{CO}_{2}$ concentration reductions.

\section{ACKNOWLEDGEMENTS}

The authors gratefully acknowledge the support of this work by the LIFE+ Programme under the responsibility of the Directorate General for the Environment of the European Commission through the agreement LIFE17 CCA/ES/00088, LIFE myBUILDINGisGREEN. 


\section{REFERENCES}

[1] IPCC, AR5 Climate change 2014: Impacts, adaptation, and vulnerability, 2014. www.ipcc.ch/report/ar5/wg2/. Accessed on 21 Feb. 2020.

[2] Fermoso, J. et al., Improvement of classroom conditions and $\mathrm{CO}_{2}$ concentrations through natural ventilation measures reinforced with NBS implementation. Presented at 2 nd Euro-Mediterranean Conference for Environmental Integration, Tunisia, Oct. 2019.

[3] Gallego, J., Arranz, B., Oteiza, A. \& Martín-Consuegra, F., Hygrothermal comfort and air quality assessment in public schools in Madrid. Study of three cases during a year. Submitted for publication.

[4] Calliari, E., Staccione, A. \& Mysiak, J., An assessment framework for climate-proof nature-based solutions. Science of The Total Environment, 656, pp. 691-700, 2019. https://doi.org/10.1016/j.scitotenv.2018.11.341.

[5] Panno, A., Carrus, G., Lafortezza, R., Mariani, L. \& Sanesi, G., Nature-based solutions to promote human resilience and wellbeing in cities during increasingly hot summers. Environmental Research, 159, pp. 249-256, 2017.

https://doi.org/10.1016/j.envres.2017.08.016.

[6] Xing, Y., Jones, P. \& Donnison, I., Characterisation of nature-based solutions for the built environment. Sustainability, 9(1), p. 149, 2017.

https://doi.org/10.3390/su9010149.

[7] Stabile, L., Massimo, A., Canale, L., Russi, A., Andrade, A. \& Dell'Isola, M., The effect of ventilation strategies on indoor air quality and energy consumptions in classrooms. Buildings, 9(5), p. 110, 2019. https://doi.org/10.3390/buildings9050110.

[8] Almeida, R.M.S.F., Pinto, M., Pinho, P.G. \& de Lemos, L.T., Natural ventilation and indoor air quality in educational buildings: Experimental assessment and improvement strategies. Energy Efficiency, 10(4), pp. 839-854, 2017.

https://link.springer.com/article/10.1007/s12053-016-9485-0.

[9] McIvor, A.E. et al., ANSI/ASHRAE Standard 62-2001, Ventilation for Acceptable Indoor Air Quality, 2001.

[10] RITE, Reglamento instalaciones térmicas en los edificios, 2013. www.minetad.gob.es/ energia/desarrollo/EficienciaEnergetica/RITE/Paginas/InstalacionesTermicas.aspx. Accessed on: 22 May 2017.

[11] de España, C.D.M., Real Decreto 485/1997, sobre disposiciones mínimas en materia de señalización de seguridad y salud en el trabajo; anexos I, II y III, 1997. www.boe.es/ buscar/doc.php?id=BOE-A-1997-8668. 